\title{
Patterns of seasonal and tidal feeding activity in the dendrochirote sea cucumber Cucumaria frondosa (Echinodermata: Holothuroidea) in the Bay of Fundy, Canada
}

\author{
Rabindra Singh ${ }^{1}$, Bruce A. MacDonald ${ }^{1, *}$, Martin L. H. Thomas ${ }^{1}$, Peter Lawton ${ }^{2}$ \\ ${ }^{1}$ Department of Biology, Centre for Coastal Studies and Aquaculture, University of New Brunswick, PO Box 5050, \\ Saint John, New Brunswick E2L 4L5, Canada \\ ${ }^{2}$ Marine Invertebrate Fisheries Division, Department of Fisheries and Oceans, Biological Station, \\ 531 Brandy Cove Road, St. Andrews, New Brunswick E5B 2L9, Canada
}

\begin{abstract}
In situ field observations of the suspension-feeding North Atlantic sea cucumber Cucumaria frondosa from the Bay of Fundy, Canada, conducted over a 3 yr period, revealed a seasonal feeding rhythm. Sea cucumbers extended their tentacles and began feeding in March/April and ceased feeding in September/October. There were significant relationships between this feeding activity. daylength and the quality of the seston, but not its concentration. Together daylength and chloropigment concentration explained $49 \%$ of the variability in the percentage of feeding sea cucumbers. Feeding activity was not significantly correlated with the distinct temperature cycle observed in the study area. Feeding activity was influenced by the state of the tide, water temperature and by daylight during some periods of the feeding season. However, for most of the year these factors appeared not to be important. Sea cucumbers increased their rate of tentacle insertion into the mouth as the quality of the seston increased. The rate of tentacle insertions increased with increasing seston chloropigment concentration but decreased with increasing current speed. These 2 environmental variables explained about $28 \%$ of the variability in tentacle insertion rates. Seston quality is likely the major environmental variable influencing seasonal feeding behaviour and feeding rate in this species.
\end{abstract}

KEY WORDS: Cucumaria frondosa - Seasonal feeding · Passive suspension feeder - Feeding rates Current - Bay of Fundy

\section{INTRODUCTION}

The feeding processes of both deposit and suspension feeders result in the transfer of large quantities of energy and matter between the pelagic and benthic ecosystems (e.g. Fréchette \& Bourget 1985, Young \& Emson 1995, Dame 1996, Loo et al. 1996). Suspension feeders influence their environment through particle depletion, nutrient cycling, and biodeposition (Jørgensen 1990). Bioturbation caused by the feeding activities of deposit feeders results in the burial of

\footnotetext{
-Addressee for correspondence. E-mail: bmacdon@unbsj.ca
}

organic material and the transfer of organic and inorganic matter to the water column (Bakus 1973, Massin 1982). Although most sea cucumbers are deposit feeders, some species are passive suspension feeders which ingest immobile or slightly mobile plankton (MacGinite \& MacGinite 1949, Hyman 1955, Jørgensen 1966, Reese 1966, Ferguson 1969, Fankboner 1978). While suspension-feeding holothurians are potential prey for several species (Francour 1997) and can occur in dense assemblages (Jordan 1972, Könnecker \& Keegan 1973, Smith \& Keegan 1985), nothing is known about the effect of their feeding activity on planktonic communities and little is known about their feeding behaviour (Massin 1982). 
Daily rhythmic behaviour is displayed by many species of echinoderms (Reese 1966). The comatulids (crinoids) Lamprometra klunzingeri and Heterometra savignyi feed actively during the night to avoid fish predation (Magnus 1963). The asteroids Astropecten polyacanthus and Luidia sarsi are most active at night, and feeding seems to be controlled by ambient light level and food availability (Mori \& Matutani 1952). Nocturnal feeding activity cued by light levels has also been recorded in several species of echinoids such as Meoma ventricosa (Chesher 1969), Cassidulus caribbearum (Gladfelter 1978), and Clypeaster rosaceus (Hammond 1982). Nelson \& Vance (1979) suggested that while the physical cue is probably light level, nocturnal foraging by the echinoid Centrostephanus coronatus results in the avoidance of diurnal predation. Diurnal activity as a predator avoidance strategy has been reported for Paracentrotus lividus (Ebling et al. 1966) and Diadema setosum (Lawrence \& HughesGames 1972).

Nocturnal feeding activity has also been observed in several deposit-feeding holothurians from a variety of habitats including Stichopus japonicus, a diurnally infaunal species (Yamanouti 1942), Holothuria scabra, a nocturnally infaunal species (Wiedmeyer 1993), H. thomasi, Actinopyga agassizi, and Euapta lappa, diurnally cryptic species (Pawson \& Caycedo 1980, Hammond 1982), and Isostichopus badionotus, $H$. mexicana, and $H$. atra, epibenthic species (Hammond 1982, Wiedmeyer 1993). The suspension-feeding sea cucumber Neopentadactyla mixta is a permanently infaunal species and feeds only at night (Könnecker \& Keegan 1973). Such nocturnal behaviour in these holothurians seems to be cued by light intensity (Bruce 1960). In the case of the suspension-feeding Sclerodactyla briareus, Stier (1933) suggested that feeding was not controlled by light but was due to an endogenous rhythm. Hunter-Rowe et al. (1977 cited in Massin 1982) reported that the feeding rhythm of the suspension-feeding Thyone fusus was related to the strength of current flow and not to tide or light levels.

Many echinoderms also display seasonal feeding behaviour (Reese 1966, Ferguson 1969). Factors such as temperature, weather conditions, and internal reproductive state have all been attributed to influence seasonal feeding activities in asteroids (Sloan 1980). Fluctuation in food availability has resulted in seasonal feeding activity in several species of asteroids such as Asterias forbesi (Mackenzie 1970), Mediaster aequalis (Mauzey et al. 1968) and Pisaster ochraceus (Mauzey 1966). Seasonal feeding has also been reported for some species of holothurians. According to Yingst (1982), seasonal spontaneous evisceration in the family Stichopodidae occurs during fall or winter, with the animals becoming dormant until regeneration of the gut occurs. Such evisceration events impose a seasonality on the deposit-feeding activity of holothurians such as Actinopyga agassizi (Mosher 1965), Stichopus tremuIus (Jespersen \& Lützen 1971), Holothuria floridana (Emson \& Wilkie 1980), and Parastichopus parvimensis (Dimcock 1977, Yingst 1982) and on the suspensionfeeding Eupentacta quinquesemita (Byrne 1985). The deposit-feeding Parastichopus californicus from the west coast of North America undergoes annual autumnal visceral atrophy resulting in seasonal feeding activity (Fankboner \& Cameron 1985). The reasons for the occurrence of seasonal evisceration or visceral atrophy in sea cucumbers are not clear; however, temperature, photoperiod, and food availability are potential factors (Byrne 1985, Fankboner \& Cameron 1985). Fish (1967) observed that the deposit-feeding sea cucumber Leptopentacta (= Cucumaria) elongata, from the British Isles, stopped feeding during the early part of October and remained dormant until late April/early May of the following year. Quiescence in the autumn to spring period has also been observed in the suspension feeders Aslia lefevrei (Costelloe \& Keegan 1984) and Neopentadactyla mixta (Smith \& Keegan 1985) from the Irish west coast, and in the deposit-feeding Stichopus japonicus from Japan (Tanaka 1958). Temperature has been suggested as the cue for such seasonal feeding behaviour (Tanaka 1958, Smith \& Keegan 1985). Quiescence in A. lefevrei and $N$. mixta has been interpreted to reflect temperature-depressed metabolism and refuge-seeking behaviour from seasonally turbulent conditions (Costelloe \& Keegan 1984, Smith \& Keegan 1985). While seasonal feeding has been observed in several species of holothurians, little is known about the factor(s), other than seasonal visceral atrophy and evisceration, that induce(s) such behaviour (Fankboner \& Cameron 1985).

Passive suspension feeders, such as Cucumaria frondosa, are dependent on the ambient water current to move water past or across their filtering structures (Warner 1977, LaBarbera 1984). There have been several studies on the influence of flow on the feeding behaviour of some groups of passive suspension feeders such as ophiuroids (LaBarbera 1978, Loo et al. 1996), crinoids (Meyer \& Lane 1976, Meyer 1979, Byrne \& Fontaine 1981, Holland et al, 1987, Leonard et al. 1988, Leonard 1989), hydroids (Harvell \& LaBarbera 1985, Hunter 1989) and octocorals (Patterson 1991a,b). In some species of gorgonians the feeding rate increased with increasing flow velocities, reached a peak and then decreased (Leversee 1976, Lasker 1981. Sponaugle \& LaBarbera 1991, Dai \& Lin 1993). A similar response in feeding rate with increasing ambient flow has been observed in the sea pen coral Ptilosarcus gurneyi (Best 1988). A combination of 3 factors determines the feeding rate of suspension feeders at differ- 
ent flow velocities: capture efficiency, rate of particle encounter, and deformation of the feeding elements (Muschenheim 1987, Leonard et al. 1988). The effects of these 3 factors on the feeding rate have received little attention in suspension-feeding holothurians. Ölscher \& Fedra (1977) estimated that the suspensionfeeding sea cucumber Oncus planci had a constant filtration efficiency and the concentration of food did not influence this efficiency in the laboratory. Costelloe \& Keegan (1984) reported different rates of tentacle insertions for Aslia lefevrei in clear and turbid waters in the field; however, they did not quantitatively monitor water quality during their observations.

Seasonal feeding activity has not been reported in ecological studies of Cucumaria frondosa from the coast of Maine and the Gulf of St. Lawrence (Jordan 1972, Hamel \& Mercier 1996). Based on stomach contents and 4 mo of SCUBA observations, however, a recent study in the Gulf of St. Lawrence suggested that there was seasonal feeding activity (Hamel \& Mercier 1998). Preliminary field observations of $C$. frondosa from the Bay of Fundy, Canada, have also indicated that they were not continuously feeding but had their tentacles withdrawn for extended periods during the year. This suggested that feeding in this species might be in response to some environmental cues. To our knowledge, no study has monitored suspension-feeding sea cucumbers in situ to determine their rates of feeding (tentacle insertions $\mathrm{min}^{-1}$ ) during ebbing and flooding tides and at the same time recorded the changes in current velocity, temperature and seston quality. The objectives of this study were 2-fold: firstly, to determine, through long-term observations, if $C$. frondosa displays any daily or seasonal feeding cycle and to determine the environmental cues influencing such activity, and secondly, to determine through short-term observations if environmental factors such as seston concentration, chloropigment concentration, current velocity, and water temperature influence the feeding rates of sea cucumbers during ebbing and flooding tides.

\section{MATERIALS AND METHODS}

Long-term feeding activity and seston determination. During the period December 1993 to May 1996, the feeding activity of Cucumaria frondosa was monitored monthly (or sometimes bimonthly) in situ off Jameson Island $\left(45^{\circ} 01.71^{\prime} \mathrm{W}, 66^{\circ} 55.74^{\prime} \mathrm{N}\right)$ in the Deer Island Archipelago of the Bay of Fundy, Canada. At this site, sea cucumbers occurred at 5 to $8 \mathrm{~m}$ depth at low tide and the tidal range was approximately $8.3 \mathrm{~m}$ (Trites \& Garrett 1983). Observations were made with a video camcorder enclosed in an underwater housing equipped with time-lapse capability. An underwater battery pack provided power to the system and to a $100 \mathrm{~W}$ underwater light. The camera and light were attached to a weighted tripod set on the bottom to record a group of 30 to 40 sea cucumbers on the rocky substratum. The camera and light were set to switch on hourly ( 1 min on and 59 min off) during each observation period. The length of the recording for each monthly (or bimonthly) sample varied from 5 to $64 \mathrm{~h}$ depending on the state of the power supply, the water temperature and whether the system functioned properly. For each sample, each of the 1 min hourly video recordings was analysed to determine the percentage of all sea cucumbers in the field of view with their tentacles extended (as when they are feeding) (Fig. 1). Hourly, daily (in cases where recordings were for $24 \mathrm{~h}$ or more) and monthly mean percentages of sea cucumbers with tentacles extended and feeding were determined. A miniature temperature logger attached to a concrete block on the bottom continuously recorded temperature at intervals of $3.2 \mathrm{~h}$ at the study site.

The concentration and quality of suspended particles were estimated at least once per month by filling three 4 l water bottles 10 to $15 \mathrm{~cm}$ off the bottom using SCUBA. Three subsamples of about 1.0 to $1.5 \mathrm{I}$ were suction filtered onto $25 \mathrm{~mm} \mathrm{GF/C} \mathrm{filters} \mathrm{for} \mathrm{determina-}$ tion of chlorophyll a concentration and total pigment concentration near the bottom. Fluorometric analyses were carried out as described by Yentsch \& Menzel (1963) and modified by Parsons et al. (1984). Chloropigment extractions were done in $90 \%$ acetone for $20 \mathrm{~h}$ at $5^{\circ} \mathrm{C}$ in darkness and concentrations were determined using a Sequoia-Turner Digital Fluorometer (Model 450). Three subsamples of about 1.2 to $2.0 \mathrm{l}$ of water were suction filtered onto washed, preignited and preweighed $25 \mathrm{~mm}$ GF/C filters to determine seston weight. Filters were rinsed with $10 \mathrm{ml}$ of isotonic

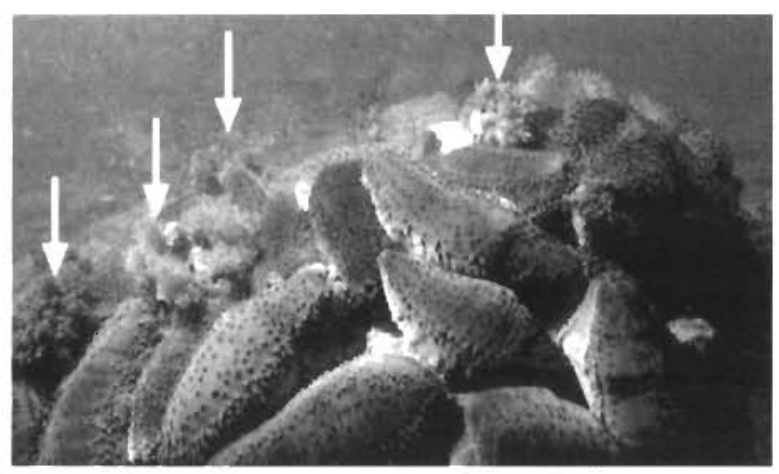

Fig. 1. An example of a mixed group of feeding and non-feeding Cucumaria frondosa. Arrows indicate individuals with tentacles extended and feeding. Photograph by Mike Strong and Maria-Ines Buzeta 
ammonium formate to remove salt and prevent cell lysing. The dry weight (DW) and ash free dry weight (AFDW) of the seston were determined by drying the filters at $80^{\circ} \mathrm{C}$ for $24 \mathrm{~h}$, weighing, combusting at $450^{\circ} \mathrm{C}$ for $12 \mathrm{~h}$ and reweighing after cooling in a desiccator (Strickland \& Parsons 1972).

Short-term feeding observations. During the period 24 May to 5 June, 1995, Cucumaria frondosa at the study site with tentacles extended were recorded in situ through 6 half-tidal cycles ( 3 ebbing and 3 flooding tides). An underwater video camera attached to a tripod secured to the substrate was used to record a group of 25 to 30 sea cucumbers. The camera was attached via a cable to a time-lapse ( 4 frames $\mathrm{s}^{-1}$ ) VCR held in a boat anchored above the site. Video recordings were analysed to obtain the rate of tentacle insertion for each sea cucumber in the field of view by determining the time for each complete tentacle insertion and withdrawal over a 15 min period during each hour of recording (Fig. 2). Current and temperature measurements were made using an electromagnetic current meter (InterOcean S4). In order to record the current velocity experienced by sea cucumbers, the S4 was suspended about $15 \mathrm{~cm}$ above the bottom on a separate tripod. The S4 integrates flow over a spherical electromagnetic field of about 1 to $2 \mathrm{~m}$; hence, a fair portion of the field was actually cutting into the substrate. The $\mathrm{S} 4$ recorded current and temperature 3 times every minute, and from these recordings hourly values were determined.

In addition to the recordings of sea cucumber activity during the flooding and ebbing tides, water samples were collected hourly. Water was pumped up to the boat via a hose secured about $10 \mathrm{~cm}$ above the surface of the substrate. Approximately 7 to 81 of water was collected and 4 subsamples $(0.8$ to 1.4 l) were immediately suction filtered, 2 onto $25 \mathrm{~mm} \mathrm{GF/C} \mathrm{filters}$ for determination of chl a concentration and total pigment concentration, and 2 onto washed, preignited and preweighed $25 \mathrm{~mm}$ GF/C filters for seston weight determination. The filters were immediately frozen in liquid nitrogen and placed in a freezer at $-20^{\circ} \mathrm{C}$ upon return to the laboratory. The filters were analysed as described above for the monthly water samples

Statistical analysis. Prior to analyses, all percentage data were arcsine transformed and then tested for normality using SAS procedure UNIVARIATE (Zar 1984, SAS 1988). If normality did not result from this transformation then nonparametric analyses were used for all tests involving percentage data. All other data were also tested for normality, and, if after transformation, the data still violated the assumption of normality, a nonparametric test was employed (Conover \& Iman 1981, SAS 1988). For all comparisons a significance level of alpha $=0.05$ was used
For the long-term seasonal feeding data, regression analyses (SAS procedure REG, SAS 1988) were performed on the daily mean percentages of sea cucumbers with tentacles extended and feeding and the means of the seston quality factors (chloropigment,
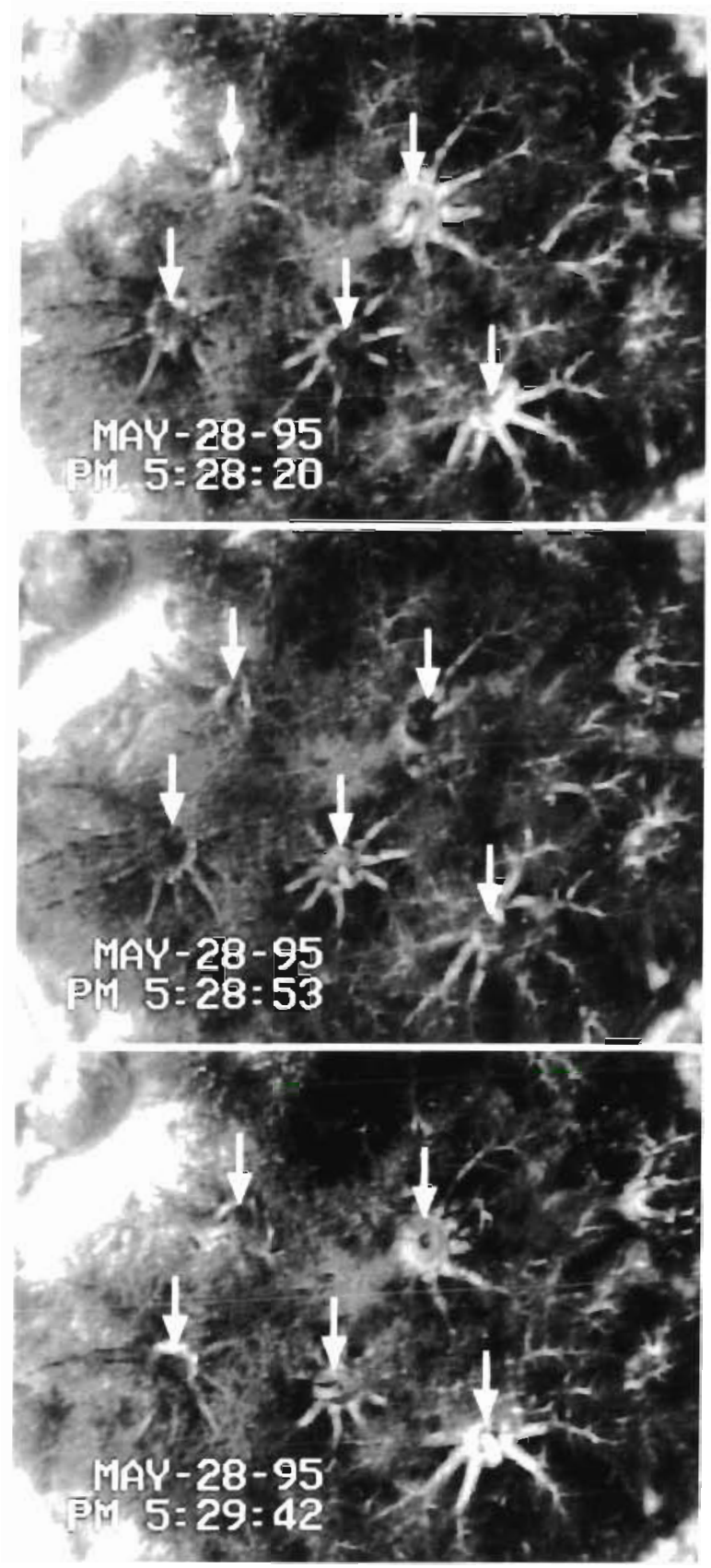

Fig. 2. Examples of video images obtained during short-term in situ observations on feeding Cucumaria frondosa. The feeding rate of individual sea cucumbers was determined from image series such as these. Note the different stages of tentacle insertion displayed by individual sea cucumbers Arrows indicate the mouths of some individuals 
DW, AFDW, and percent organics in seston). The percentage of feeding sea cucumbers was also regressed against temperature and daylength. Based on the results of these regressions, a further multivariate stepwise regression analysis was performed to determine which combination of environmental variables would explain the most variability in the percentage of sea cucumbers with tentacles extended and feeding (SAS procedure REG, SAS 1988). The relationships among environmental variables were tested using Spearman's correlation analyses (SAS procedure CORR, SAS 1988).

Visual inspection of all sampling dates indicated that recordings of feeding activity could be subjectively categorized into 2 groups: those which displayed minimal variations throughout the day (either all with tentacles extended and feeding, or all with tentacles withdrawn), and those in which the percentage of feeding sea cucumbers varied. From the recordings, therefore, the data from 8 samples (dates) in which the percentages of feeding sea cucumbers varied were selected for further analyses. In order to test whether these patterns were related to hourly stages of the tide or to changes in water temperature during the tidal cycle, Spearman's correlation analyses were performed (SAS procedure CORR, SAS 1988). These 8 dates were also used to test if the percentages of sea cucumbers with tentacles extended and feeding in the dark were significantly different from the percentages feeding in the daylight hours. On these 8 selected dates, water temperatures during the day and night were also tested for significant differences using $t$-tests (SAS procedure TTEST or NPAR1WAY, SAS 1988).

Feeding rates (tentacle insertions $\mathrm{min}^{-1}$ ) obtained from the short-term observations were regressed against seston chloropigment concentration $\left(\mu \mathrm{g} \mathrm{l}^{-1}\right)$, weight ( $\mathrm{mg} \mathrm{l}^{-1}$ ) and percent organics of the seston, and against current velocity $\left(\mathrm{cm} \mathrm{s}^{-1}\right)$ and water temperature $\left({ }^{\circ} \mathrm{C}\right.$ ) (SAS procedure REG, SAS 1988). Multivariate stepwise regression analysis was performed to determine which combination of environmental variables would explain the most variability in the tentacle insertion rate (SAS procedure REG, SAS 1988).
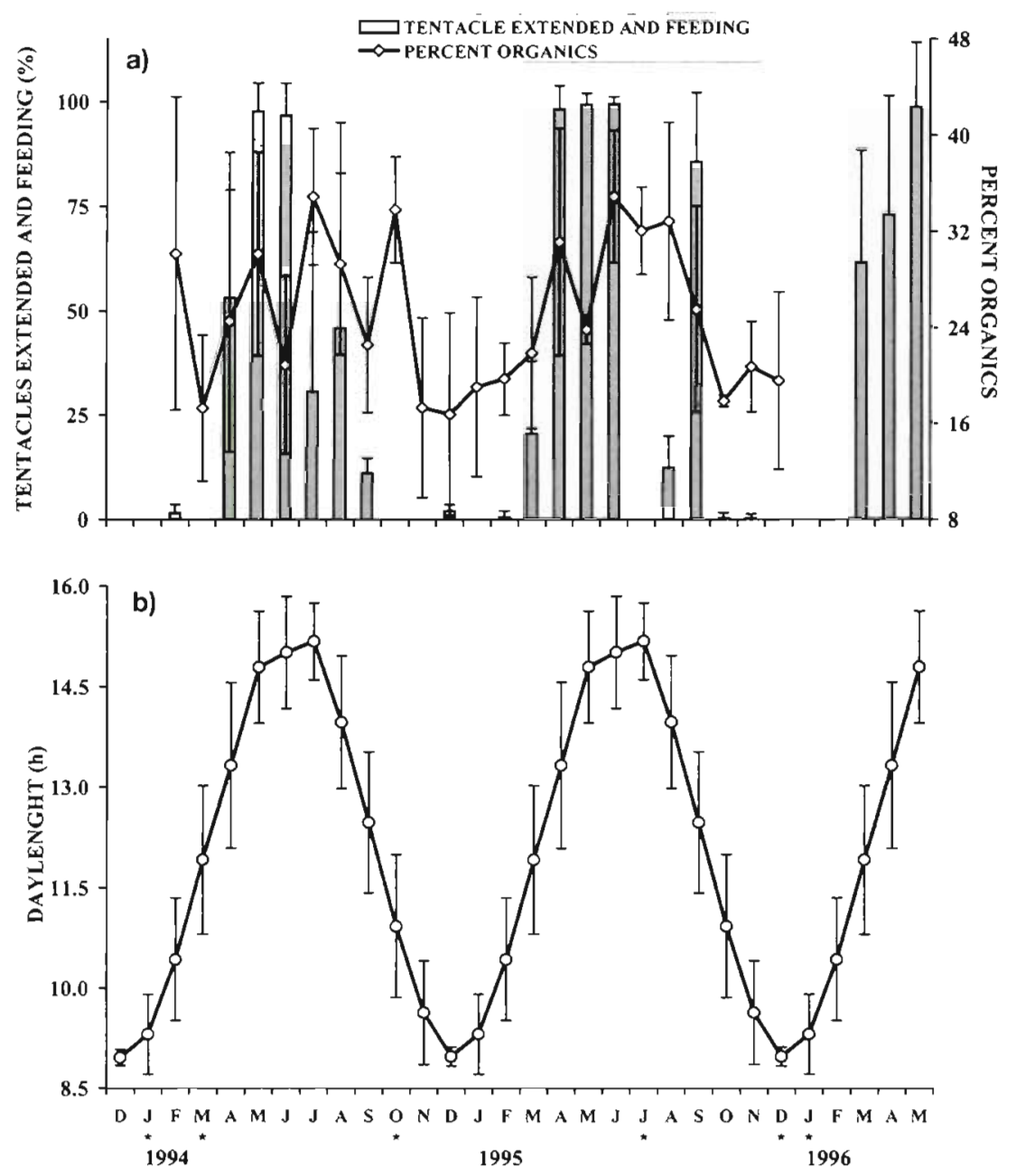

Fig. 3. Monthly percentage of Cucumaria frondosa with tentacles extended and feeding (mean \pm SD) (represented by the bars) over the observation period. (a) (-) Monthly percent organics of the seston ( $\diamond)$ (mean \pm SD). Data for percent organics of the seston for 1996 were not available. (b) (-) Plot represents the corresponding monthly daylength (mean \pm SD). (*) months in which the percentages of sea cucumbers with tentacles extended and feeding were not obtained

\section{RESULTS}

\section{Long-term feeding activity}

Feeding activity was greatest in April to August/September and lowest (or nonexistent) in October to February/March (Fig. 3). Generally, the standard deviations were greatest in the months that indicated the start and end of the feeding season, because at these times feeding activity of sea cucumbers was variable (the percentage of sea cucumbers with extended tentacles and feeding can vary anywhere from 0 to $100 \%$ ). In this study, the strongest predictive relationship was obtained between the percentage of sea cucumbers with tentacles extended and feeding and 
Table 1. Regression analyses performed on the daily (percentage Cucumaria frondosa with tentacles extended and feeding, temperature, daylength) and monthly (seston quality) means of the variables using the SAS procedure REG (SAS 1988). Correlation among environmental variables were done using Spearman's rank analyses (SAS procedure CORR, SAS 1988). 'Significant at the 0.05 level

\begin{tabular}{|c|c|c|c|c|}
\hline $\begin{array}{l}\text { Regressions (depend } \\
\text { Independent variable }\end{array}$ & $\begin{array}{l}\text { dent variable: } \\
\text { le } \quad F\end{array}$ & $\begin{array}{l}\text { percent } \\
r^{2}\end{array}$ & $\begin{array}{l}\text { age feeding) } \\
\text { Probability }\end{array}$ & $\mathrm{n}$ \\
\hline Daylength & 53.44 & 0.44 & $<0.001$ & 70 \\
\hline Percent organics & 35.05 & 0.39 & $<0.001^{*}$ & 57 \\
\hline Chloropigment conc. & 13.00 & 0.17 & $<0.001^{\circ}$ & 67 \\
\hline Absolute organics & 7.46 & 0.12 & $<0.009^{\circ}$ & 57 \\
\hline Dry weight & 0.003 & 0.001 & 0.957 & 57 \\
\hline Ash-free DW & 1.95 & 0.03 & 0.168 & 57 \\
\hline Temperature & 0.06 & 0.001 & 0.811 & 70 \\
\hline Month & 1.40 & 0.02 & 0.242 & 70 \\
\hline \multicolumn{5}{|l|}{ Correlations } \\
\hline Variable 1 & Variable 2 & r & Probability & $\mathrm{n}$ \\
\hline Chloropigment conc. & Daylength & +0.61 & $<0.001^{\circ}$ & 71 \\
\hline Percent organics & Daylength & +0.71 & $<0.001^{\circ}$ & 71 \\
\hline Chloropigment conc. & Temperature & +0.53 & $<0.001^{\circ}$ & 71 \\
\hline
\end{tabular}

daylength $\left(\mathrm{r}^{2}=0.44, F_{1,68}=53.44, \mathrm{p}<0.001\right)$ (Fig. 3, Table 1). But daylength is confounded with several other variables. The percentage of Cucumaria frondosa with tentacles extended and feeding was also significantly related to indicators of seston quality such as percent organics and chloropigment concentration $\left(\mathrm{r}^{2}=0.39, F_{1,55}\right.$ $=35.05, \mathrm{p}<0.001$ and $\mathrm{r}^{2}=0.17, F_{1,65}=12.00, \mathrm{p}<$ 0.001 , respectively) (Figs. $3 \& 4$, Table 1). In addition to daylength, chloropigment and organics also tended to peak at the same time as the mean percentage of sea cucumbers with tentacles extended and feeding (Figs. 3 \& 4). The mean percentage of sea cucumbers with tentacles extended and feeding was lowest when daylength, chloropigment concentration and percent organics were lowest. Daylength was significantly correlated with percent organics and with chloropigment concentration $(r=0.71, p<0.001$,

Fig. 4. Monthly percentage of Cucumaria frondosa with tentacles extended and feeding (mean \pm SD) (represented by the bars) over the observation period. (a) (-_) Monthly seston chloropigment concentration $\left(\mu \mathrm{g} \mathrm{l}^{-1}\right)(0)$ (mean $\pm \mathrm{SD}$ ). Chloropigment concentration was not recorded for the months of January, February and May 1996. (b) (-) Plot represents the corresponding monthly water temperature $\left({ }^{\circ} \mathrm{C}\right.$ ) (O) (mean \pm $\mathrm{SD}$ ) (*) months in which the percentages of sea cucumbers with tentacles extended and feeding were not obtained $\mathrm{n}=61$ and $\mathrm{r}=0.61, \mathrm{p}<0.001, \mathrm{n}=71$, respectively) Results of the multivariate regression analysis indicate that together daylength and chloropigment concentration accounted for $49 \%$ of the variability in the percentage of sea cucumbers with tentacles extended and feeding $\left(\mathrm{r}^{2}=0.49, F_{2.54}=25.56, \mathrm{p}<0.001\right)$. Percent organics was not significant in the multivariate regression model. On the monthly time scale, there was no significant relationship between the mean percentage of sea cucumbers with tentacles extended and feeding and the mean DW or mean AFDW of the seston (Table 1). Feeding activity was weakly related to the absolute organics $\left(\mathrm{r}^{2}=0.12, F_{1,55}=7.46, \mathrm{p}<0.008\right)$ of the seston, suggesting that total organics was not as important as its percentage in the seston in influencing the feeding activity of sea cucumber.

Although there was a strong seasonality in feeding activity with daylength and seston quality, there was no significant relationship between the mean percentage of sea cucumbers with tentacles extended and feeding and the time of year (months) (Table 1). Mean monthly percentage of sea cucumbers with tentacles extended and feeding and mean monthly temperature

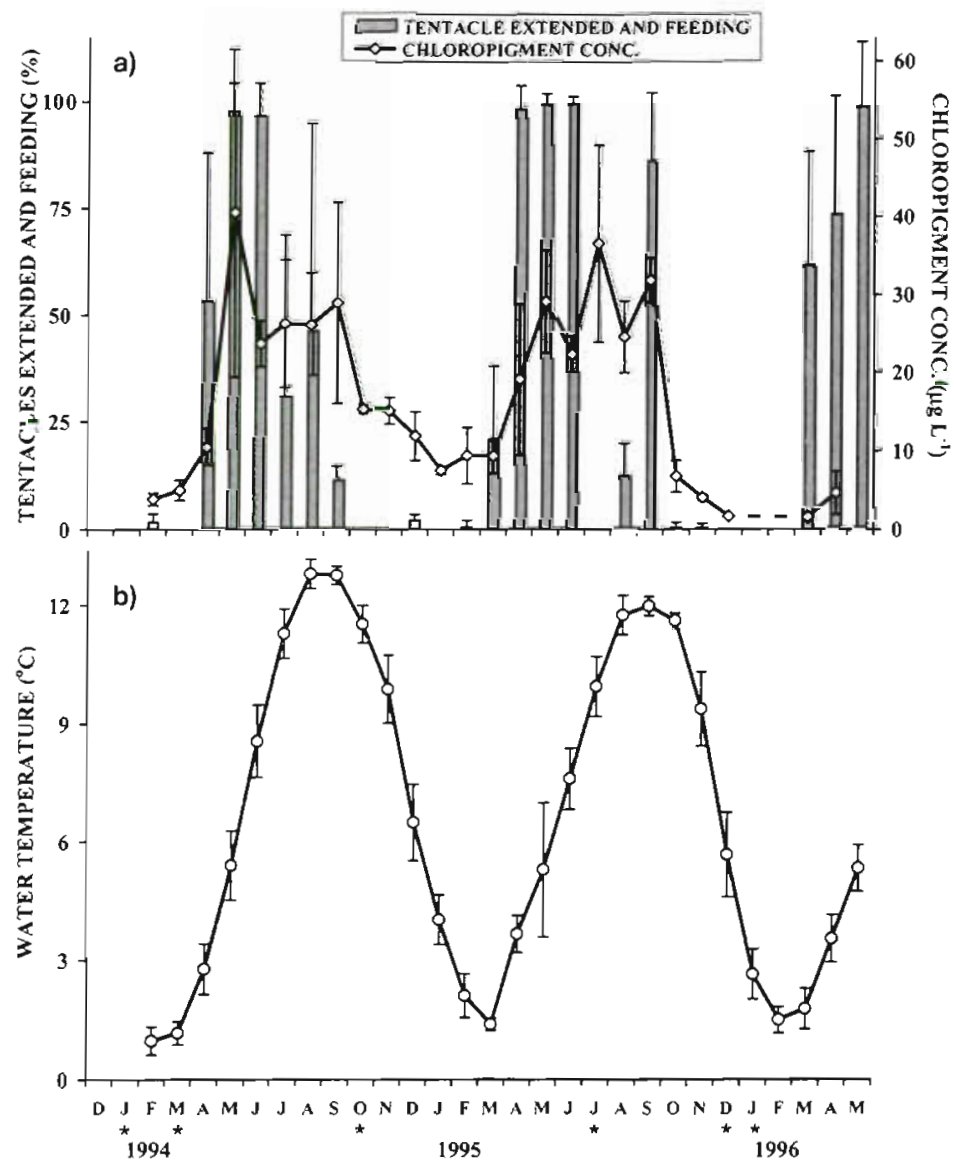


Table 2. Spearman's rank correlation analyses performed on data from selected dates (SAS procedure CORR, SAS 1988). Variables are percentage of Cucumaria frondosa with tentacles extended and feeding, water temperature and hourly stages of the tide. 'Significant at the 0.05 level

\begin{tabular}{|lccccccc|}
\hline Date & \multicolumn{3}{c}{$\begin{array}{c}\text { \% feeding and } \\
\text { temperature }\end{array}$} & \multicolumn{3}{c|}{ \% feeding and } \\
& $\mathrm{r}$ & $\mathrm{p}$ & $\mathrm{n}$ & $\mathrm{r}$ & $\mathrm{p}$ & $\mathrm{n}$ \\
\hline & & & & & & \\
\hline 7 Apr 1994 & +0.58 & $<0.001^{*}$ & 52 & -0.01 & 0.953 & 52 \\
14 Jul 1994 & +0.06 & 0.677 & 44 & -0.40 & $<0.008^{*}$ & 44 \\
29 Jul 1994 & -0.06 & 0.656 & 63 & -0.20 & 0.115 & 63 \\
29 Aug 1994 & +0.35 & $<0.014^{*}$ & 50 & -0.24 & 0.091 & 50 \\
14 Aug 1995 & -0.21 & 0.127 & 54 & -0.35 & $<0.009^{\circ}$ & 54 \\
11 Sep 1995 & -0.15 & 0.295 & 54 & -0.23 & 0.098 & 54 \\
15 Mar 1996 & -0.12 & 0.352 & 64 & -0.03 & 0.804 & 64 \\
7 Apr 1996 & -0.17 & 0.194 & 58 & +0.16 & 0.243 & 58 \\
\hline
\end{tabular}

over the observation period are shown in Fig. 4. Temperature ranged from 0 to $14^{\circ} \mathrm{C}$ and Cucumaria frondosa appeared to extend their tentacles and feed as the temperature began to increase and stopped feeding as the temperature peaked. There was no significant relationship between the percentages of sea cucumbers with tentacles extended and feeding and the mean monthly water temperatures (Table 1).

Correlation analyses of percentage of sea cucumbers feeding with temperature or tidal state on the 8 selected dates are shown in Table 2 . Significant correlations were found for 2 dates between the percentage of sea cucumbers with tentacles extended and feeding and the temperature (7 April 1994, $\mathrm{r}=0.58, \mathrm{p}$ $<0.001, \mathrm{n}=52$ and 29 August 1994, $\mathrm{r}=$ $0.35, p<0.014, n=50$ ). The percentages of sea cucumbers with tentacles extended and feeding were also significantly correlated with the state of the tide on 2 occasions (14 July 1994, $\mathrm{r}=$ $-0.40, \mathrm{p}<0.008, \mathrm{n}=52$ and 14 August 1995, $\mathrm{r}=-0.35, \mathrm{p}<0.009, \mathrm{n}=54$ ). No other correlations were significant (Table 2). The percentages of sea cucumbers with tentacles extended and feeding during the daylight hours and at night were significantly different on 4 out of 8 occasions (Table 3). Of the $4 \mathrm{~d}$ that the percentages of sea cucumbers with tentacles extended and feeding were significantly different between day and night, more sea cucumbers fed at night than during the day on 3 of these days. Day and nighttime temperatures were also significantly different on 2 dates (29 August 1994 and 11 September 1995) (Table 3).
Table 3. $t$-tests performed on the data from selected dates comparing the percentage of Cucumaria frondosa with tentacles extended and feeding in the day and the night, and comparing the water temperatures during the day and night (SAS procedure TTEST or NPAR1WAY, SAS 1988). 'Significant at the 0.05 level

\begin{tabular}{|c|c|c|c|c|c|c|}
\hline \multirow[t]{2}{*}{ Date } & \multicolumn{3}{|c|}{ Percentage feeding } & \multicolumn{3}{|c|}{ Temperature } \\
\hline & $\begin{array}{l}t \text { or } z \\
\text { value }\end{array}$ & $\begin{array}{c}\text { Total } \\
\mathrm{n}\end{array}$ & $\mathrm{p}$ & $\begin{array}{l}\text { tor } z \\
\text { value }\end{array}$ & $\begin{array}{c}\text { Total } \\
\mathrm{n}\end{array}$ & p \\
\hline 7 Apr 1994 & $-1.231^{\mathrm{a}}$ & 52 & 0.218 & 0.857 & 52 & 0.395 \\
\hline 14 Jul 1994 & $-0.874^{\mathrm{a}}$ & 44 & 0.382 & $-0.833^{\mathrm{a}}$ & 44 & 0.405 \\
\hline 29 Jul 1994 & $-2.711^{\mathrm{a}}$ & 63 & $<0.007^{\circ}$ & $1.050^{\mathrm{a}}$ & 63 & 0.293 \\
\hline 29 Aug 1994 & $3.032^{\mathrm{d}}$ & 50 & $<0.002^{\circ}$ & -3.387 & 50 & $<0.002^{*}$ \\
\hline 14 Aug 1995 & -1.301 & 54 & 0.208 & $-3.395^{a}$ & 54 & $<0.001^{\circ}$ \\
\hline 11 Sep 1995 & $-2.172^{a}$ & 54 & $<0.030^{\circ}$ & 4.583 & 54 & $<0.001^{\circ}$ \\
\hline 15 Mar 1996 & -2.527 & 64 & $<0.014^{\circ}$ & -1.640 & 64 & 0.106 \\
\hline 7 Apr 1996 & 0.470 & 58 & 0.640 & -1.903 & 58 & 0.062 \\
\hline
\end{tabular}

\section{Short-term feeding observations}

Hourly means of the recorded variables for the 6 half-tidal cycles were grouped based on the state of the tide (low tide-high tide-low tide). The end results were mean trends that ran from low tide up to a high and back to low tide (Fig. 5). Tentacle insertion rate increased with increasing chloropigment concentration of the seston $\left(\mathrm{r}^{2}=0.23, F_{1,64}=19.10, \mathrm{p}<0.001\right)$ (Fig. 5). Insertion rates were also significantly related to seston dry weight $\left(\mathrm{r}^{2}=0.11, F_{1,64}=7.74, \mathrm{p}<0.007\right)$

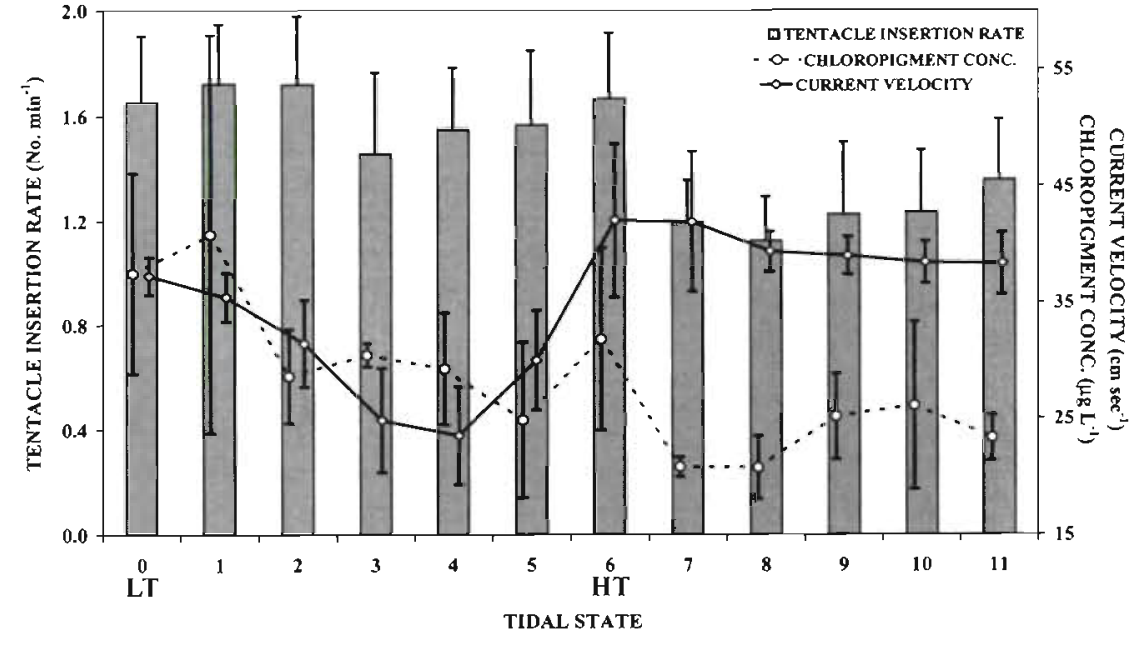

Fig. 5. Tentacle insertion rates (no. $\mathrm{min}^{-1}$ ) of Cucumaria frondosa (mean $\pm \mathrm{SD}$ ) during flooding and ebbing tides (represented by the bars). Lines represent seston chloropigment concentration $\left(\mu \mathrm{g} \mathrm{l}^{-1}\right)\left(-----\right.$, o) and current speed $\left(\mathrm{cm} \mathrm{s}^{-1}\right)$ $(-, \circ)$ (mean \pm SD) during the observation period. Hourly tidal state is represented by numbers 0 to 11 with $0=$ low tide (LT) and $6=$ high tide (HT) 
(not shown), but not with percent organics of the seston $\left(\mathrm{r}^{2}=0.003, F_{1,64}=0.16, \mathrm{p}>0.692\right)$. Tentacle insertion rates decreased with increasing current velocity $\left(\mathrm{r}^{2}=0.12, F_{1,64}=8.97, \mathrm{p}<0.004\right)$ (Fig. 5). Results of the multivariate stepwise regression analysis indicate that together chloropigment concentration and current velocity explained about $28 \%$ of the variability in tentacle insertion rate. Other variables were not significant in the multivariate regression model. Current velocity remained high at both low tide and high tide, indicating that there was a very short slackwater at the study site. Tentacle insertion rates were not significantly related to the small change in temperature (7.1 to $\left.7.6^{\circ} \mathrm{C}\right)\left(\mathrm{r}^{2}=0.03, F_{1,64}=1.74, \mathrm{p}>0.191\right)$.

\section{DISCUSSION}

There was a distinct seasonality in the feeding behaviour of Cucumaria frondosa in the Bay of Fundy. During the months of October to February/March sea cucumbers in the Bay of Fundy stopped feeding. Seasonal feeding activity in the field was not previously reported from the coast of Maine (Jordan 1972) and the Gulf of St. Lawrence (Hamel \& Mercier 1996). Recently, however, based on stomach content analysis and SCUBA observations, Hamel \& Mercier (1998) suggested that in the Gulf of St. Lawrence, C. frondosa fed mainly during the spring and summer. Long periods of cessation in feeding have previously been observed in both suspension-feeding and depositfeeding sea cucumbers. Engstrom (1982) reported that the suspension-feeding sea cucumber $C$. lubrica, from Puget Sound, stopped feeding for a period of 6 mo (September to February). Aslia lefevrei, a suspension feeder, also stopped feeding from December to March (Costelloe \& Keegan 1984). Neopentadactyla mixta, a suspension feeder, stopped feeding from September/October until March/April of the following year (Smith \& Keegan 1985). The deposit-feeder Leptopentacta (= Cucumaria) elongata also stopped feeding from October to April/May of the following year (Fish 1967). The West Pacific sea cucumber Stichopus japonicus, a deposit feeder, became quiescent when the temperature reached $24.5^{\circ} \mathrm{C}$ in the autumn (September to October) (Tanaka 1958, Choe 1963). Feeding activity in $C$. frondosa began in the spring (March to April) when the mean monthly daylength, water temperature and chloropigment concentration started increasing. As daylength, temperature and seston quality start rising about the same time, it is necessary to examine which factor (or combination of factors) cause(s) the feeding response in C. frondosa

In the Bay of Fundy, sea cucumbers started to feed in the spring when daylength was increasing and stopped feeding when daylength was shortening (Fig. 3). The percentage of sea cucumbers with tentacles extended and feeding was significantly related to daylength $\left(\mathrm{r}^{2}=0.44, \mathrm{p}<0.001\right)$ (Table 1). Fish (1967) suggested that for Leptopentacta (= Cucumaria) elongata, daylength does not seem to be the major environmental cue as the start or end of feeding activity was not related to the seasonal equinox. In the Bay of Fundy, daylength was significantly correlated with both percent organics and chloropigment concentration (Table 1), and this complicates the interpretation of the significant relationship observed between daylength and feeding activity. Multivariate stepwise regression analysis, however, indicated that $49 \%$ of the variability in the percentage of sea cucumber with tentacles extended and feeding can be explained by a combination of daylength and chloropigment concentration. This supports the view that the seasonal feeding activity of Cucumaria frondosa may be in response to more than one of these environmental variables and re-emphasizes the importance of chloropigment concentration in the feeding activity of sea cucumbers.

According to Fankboner \& Cameron (1985), physiological and behavioural evidence indicates that seasonal diapause in Parastichopus californicus was most likely caused by food availability rather than by photoperiod. Indeed, changes in the quality of the seston, the percent organics and chloropigment concentration were significantly related to the feeding activity of Cucumaria frondosa in the field (Figs. $3 \& 4$, Table 1 ). There was no relationship between feeding activity and weight of the seston, suggesting that $C$. frondosa was responding to the quality (chloropigment concentration, percent organics) and not the quantity of the seston. In the Gulf of St. Lawrence, sea cucumbers also appeared to feed during the times of the year when food was abundant (Hamel \& Mercier 1998). These findings in the field are consistent with laboratory studies by Singh et al. (1998). There was close agreement between the feeding response of sea cucumbers to chloropigment concentration in the field observations and laboratory experiments, with maximal numbers of sea cucumbers with tentacles extended and feeding occurring between 40 to $50 \mathrm{\mu g} \mathrm{l}^{-1}$, while minimal numbers occurred below $10 \mu \mathrm{g} \mathrm{l}^{-1}$ in both studies.

Phytoplankton abundance in the Bay of Fundy is low from October to early March and rises in late March through to May, after which it gradually declines to low levels in July and August (Lacalli 1981, Martin et al. 1995). There is a modest secondary peak in September and early October (Lacalli 1981, Martin et al. 1995). Seasonal variations in phytoplankton abundance as seen by changes in chloropigment concentration in Fig. 4 corresponded to the periods of feeding activity in Cucumaria frondosa in the Bay of Fundy. 
Fankboner \& Cameron (1985) suggested that feeding activity in the deposit-feeding sea cucumber Parastichopus californicus was closely related to the availability of plankton. Deposit-feeding sea cucumbers feed on surface sediments, which are enriched by the supply of detritus and surface algae from the plankton. Sea cucumbers in the field tended to go into diapause when the plankton bloom ended in August and, in the laboratory, starved sea cucumbers also went into diapause (Fankboner \& Cameron 1985).

There was no significant relationship between the mean percentage of sea cucumbers with tentacles extended and feeding and the mean temperature. Cucumaria frondosa initiated feeding when the water temperature started rising $\left(1\right.$ to $\left.3^{\circ} \mathrm{C}\right)$ and stopped when the temperature peaked or began declining (11 to $14^{\circ} \mathrm{C}$ ) (Fig. 4). Temperature, however, does not appear to be the single environmental cue that initiated or stopped feeding in the field. There was no definite threshold temperature that triggered feeding (extension of tentacles) and closing (withdrawal of tentacles) in $C$. frondosa because they were observed to be feeding in the spring at the same temperatures at which feeding ceased in the autumn. The spring increase in temperature has been suggested as the possible environmental cue for feeding to begin in some species of sea cucumbers (Pawson 1966). In the case of the deposit-feeding Stichopus japonicus temperature appeared to be the major cue because an upper water temperature of $24.5^{\circ} \mathrm{C}$ caused feeding activity to stop (Tanaka 1958). Smith \& Keegan (1985) suggested that the 6 to $8 \mathrm{mo}$, autumn to spring, quiescence in Neopentadactyla mixta was cued by temperature and was related to refuge seeking from seasonally turbulent conditions. They hypothesized that the feeding process was metabolically demanding, hence the energy budget of the feeding process would not be met by the poor quality of the winter seston. C. frondosa did not display a temperature threshold for feeding to begin or stop, and the sea cucumbers were not observed to move to seek refuge after they stopped feeding. It is possible, however, that as in $N$. mixta the metabolic cost of feeding during the winter for $C$. frondosa was not met because of the poor seston quality. This seasonal feeding pattern was not related to the presence or absence of planktonic larvae of the same species in the water column. Lacalli (1981) found that, in the Bay of Fundy, larvae were present from mid-April to late May, and this period spans only a portion of the time when C. frondosa is feeding.

During these long-term observations, there were periods of feeding activity that indicated response by Cucumaria frondosa to changes in water temperature and to the state of the tide (Table 2). These responses, however, were not consistent in all 3 of the feeding seasons observed. Even though significant correlations were sometimes present, there was no indication that sea cucumbers were responding primarily to tidal and temperature changes. This was so because there were times in the winter when there was no feeding for extended periods and other times in the spring when they were all feeding continuously for weeks. As the percent organics and chloropigment concentration of the seston seem to be important in initiating feeding activity in $C$. frondosa, then it will also be good to obtain data on the changes in these 2 factors during a tidal cycle, especially at the times of the year when the present data indicate significant correlations between the percentage of sea cucumbers with tentacles extended and feeding and the temperature and hourly stages of the tide.

The percentages of sea cucumbers with tentacles extended and feeding were significantly different during day and night for 4 of the 8 dates examined (Table 3). The percentages of sea cucumbers feeding in the night were greater for 3 of these 4 recordings. As one of these dates had more sea cucumbers feeding in the day than in the night, this indicates that there was not complete preference for either day or night by Cucumaria frondosa for feeding. It is possible, however, that sea cucumbers switch to day or night feeding to avoid tentacle-cropping predation by fishes (e.g. de Vlas 1979, Peterson \& Skilleter 1994, Skilleter \& Peterson 1994, Francour 1997). On 2 of these 4 dates (29 August 1994 and 11 September 1995), temperature was also significantly different during the day and night (Table 3). Only on 29 August 1994, however, was there a significant correlation between the percentage of sea cucumbers with tentacles extended and feeding and the temperature $(\mathrm{r}=0.35, \mathrm{p}<0.014, \mathrm{n}=50$ ) (Table 2), making it difficult to determine which single environmental factor they were responding to on this date. Here again, data on the chloropigment concentration during the day and night would be useful.

\section{Short-term observations}

The rate of tentacle insertion by Cucumaria frondosa in their natural environment increased with increasing chloropigment concentration and seston weight (Fig. 5). During the spring, when these observations were made, the seston weight and chloropigment concentration can be expected to be correlated. According to Olscher \& Fedra (1977), the filtering efficiency of the sea cucumber Oncus planci in the laboratory was constant at food concentrations up to 3 orders of magnitude above average natural values. If this is also true of C. frondosa, then as the seston weight and chloro pigment concentration increased more food would be 
captured on the tentacles. The presence of more food on the tentacles may be detected by sea cucumbers because of the mechanosensory and chemosensory abilities of the tentacles (Fankboner 1978, Smith 1983, Costelloe \& Keegan 1984). Sea cucumbers responded to the increase in particles by increasing their rate of tentacle insertion into the mouth. This observation in the field is consistent with laboratory observations that the rate of tentacle insertions increased as the chloropigment concentration increased (Singh et al. 1998). Schaller (1973) also hypothesized that in Aslia lefevrei and Pawsoni saxicola tentacles are only inserted into the mouth if the trapped particles have nutritional value, implying that tentacles are capable of sensing the chemical value of particles (Massin 1982).

The rate of tentacle insertions (no. $\mathrm{min}^{-1}$ ) decreased with increasing current velocity (Fig. 5). At a constant concentration, increases in flow rates should cause increased contact between the feeding tentacles and particles in the seston, resulting in increased insertion rates (Muschenheim 1987. Shimeta \& Jumars 1991). When the flow speed increases, deformation of the feeding tentacles results in a reduction in the surface area available for particle capture (Patterson 1984, Best 1988, Shimeta \& Jumars 1991, Eckman \& Duggins 1993). Particle retention efficiency can also be expected to decrease as the ambient flow increases above some critical level (Shimeta \& Koehl 1997). During the field observations of Cucumaria frondosa current speed was negatively correlated with the chloropigment concentration and DW of the seston. Together, however, chloropigment concentration and current velocity explained about $28 \%$ of the variability in tentacle insertion rate. It is possible that a combination of decreasing seston concentration, deformation of the tentacles (as observed in the video recordings) and decreased retention efficiency resulted in a decrease in the flux of particles encountered by the feeding tentacles as current velocity increased. The reduction of particles on the tentacles of sea cucumbers along with the physical resistance on tentacle movement into the mouth by high velocity water were the likely factors for the observed decrease in tentacle insertions. There appeared to be no clear peak in the feeding rate of sea cucumbers from the observations in the field (Fig. 5). As in other passive suspension feeders, however, there was a decline in feeding rate at higher current speeds (Best 1988, Leonard et al. 1988, Sponaugle \& LaBarbera 1991, Dai \& Lin 1993). The largest change in the insertion rate occurred at high tide ( 6 vs 7 h), and while the current velocity was high at this time, the chloropigment concentration decreased, indicating a tidal influence on seston quality. For the purposes of comparison, the flux of particulate organic matter available to sea cucumbers at the study site ranged between 6.33 and $19.21 \mathrm{mg} \mathrm{cm}^{-2}$ $\mathrm{s}^{-1}$, which is lower than values $\left(60.3\right.$ to $\left.74.3 \mathrm{mg} \mathrm{cm}^{-2} \mathrm{~s}^{-1}\right)$ reported for Great Sound, New Jersey (Grizzle \& Morin 1989).

During these short-term feeding observations, insertion rates were not influenced by the small change in temperature $\left(7.1\right.$ to $\left.7.6^{\circ} \mathrm{C}\right)$. It is possible that this change in temperature was too small to have a significant influence on the rate of tentacle insertions. Feeding rate was also not significantly related to percent organics of the seston $\left(\mathrm{r}^{2}=0.003, \mathrm{p}>0.692\right)$. It should be noted, however, that chloropigment concentration was not significantly correlated with the percent organics of the seston $(r=-0.05, p>0.720, n=66)$. As described above in the long-term seasonal feeding study, the chloropigment concentration and the percent organics of the seston are usually strongly correlated. This was not, however, found to be the case during the flooding and ebbing tides that were monitored, indicating that there were fluctuations in the percent of organics in the seston.

There have been few in situ studies of feeding in holothurians (Könnecker \& Keegan 1973, Costelloe \& Keegan 1984). To our knowledge no one has used the approach we have used. This study indicates that the feeding response of sea cucumbers is complex. Several environmental variables (daylength, chloropigment concentration and percent organics of the seston) were significantly related to the feeding activity of Cucumaria frondosa. In temperate waters, seston quality and quantity change seasonally. Daylength also changes seasonally and was significantly correlated with chloropigment concentration and with percent organics. Daylength and chloropigment concentration combined accounted for $49 \%$ of the variability in the percentage of sea cucumbers with tentacles extended and feeding. Both short- and long-term observations, along with laboratory studies (Singh et al. 1998), however, point to seston quality (chloropigment concentration, percent organics) as being important in the feeding activity of sea cucumbers. This study indicates that both seston quality and current velocity influence feeding rate; hence, it would be interesting to determine the response of sea cucumbers to changes in these 2 factors under controlled laboratory conditions.

Acknowledgements. This paper forms part of a thesis submitted by R.S. in partial fulfillment of the requirements for Doctor of Philosophy at the Biology Department, University of New Brunswick in Saint John, NB, Canada. Funding for this project was provided by Natural Science and Engineering Research Council of Canada grants to B.A.M. and M.L.H.T and by the Canadian Department of Fisheries and Oceans (scientific authority, P.L.). Dr K. Halcrow, Dr C. Peterson and 2 anonymous reviewers provided comments on an earlier draft of this manuscript. We would like to thank the captains of the 
Research Vessels 'Mary $O$ ' and 'Pandalus III'. R.S. also thanks the SCUBA divers from the Department of Fisheries and Oceans, St. Andrews, NB and University of New Brunswick in Saint John, NB, who served as diving buddies on the numerous dives during this study. This is contribution number 24 of the Centre for Coastal Studies and Aquaculture, University of New Brunswick in Saint John, NB.

\section{LITERATURE CITED}

Bakus GJ (1973) The biology and ecology of tropical holothurians. In: Jones OA, Endean R (eds) Biology and geology of coral reefs, Vol II. Biology 1. Academic Press, New York, p 325-367

Best BA (1988) Passive suspension feeding in a sea pen: effects of ambient flow on volume flow rate and filtering efficiency. Biol Bull 175:332-342

Bruce VG (1960) Environmental entrainment of circadian rhythms. Cold Spring Harbour Symp Quant Biol 25:19-47

Byrne M (1985) Evisceration behaviour and the seasonal incidence of evisceration in the holothurian Eupentacta quinquesemita (Selenka). Ophelia 24:75-90

Byrne M, Fontaine AR (1981) The feeding behaviour of Florometra serratissima (Echinodermata: Crinoidea). Can J Zool 59:11-18

Chesher RH (1969) Contributions to the biology of Meoma ventricosa (Echinoidea: Spatangoida). Bull Mar Sci 19: $72-110$

Choe S (1963) Biology of the Japanese sea cucumber, Stichopus japonicus Selenka. PhD thesis, Pusan National University (in Japanese with English summary)

Conover WJ, Iman RL (1981) Rank transformations as a bridge between parametric and nonparametric statistics. Am Stat 35:124-129

Costelloe J, Keegan BF (1984) Feeding and related morphological structures in the dendrochirote Aslia lefevrei (Holothuroidea: Echinodermata). Mar Biol 84:135-142

Dai CF, Lin MC (1993) The effects of flow on feeding of three gorgonians from southern Taiwan. J Exp Mar Biol Ecol $173: 57-69$

Dame RF (1996) Ecology of marine bivalves: an ecosystem approach. CRC Press, Boca Raton

de Vlas J (1979) Annual food intake by plaice and flounder in a tidal flat area in the Dutch Wadden Sea, with special reference to consumption of regenerating parts of macrobenthic prey. Neth J Sea Res 13:117-153

Dimcock RV (1977) Effects of evisceration on oxygen consumption by Stichopus parvimensis Clark (Echinodermata: Holothuroidea). J Exp Mar Biol Ecol 28:125-132

Ebling JF, Hawkins AD, Kitching JA, Muntz L, Pratt VM (1966) The ecology of Lough Ine. XVI. Predation and diurnal migration in the Paracentrotus community. J Anim Ecol 35:559-566

Eckman JE, Duggins DO (1993) Effects of flow speed on growth of benthic suspension feeders. Biol Bull 185:28-41

Emson RH, Wilkie IC (1980) Fission and autotomy in echinoderms. Oceanogr Mar Biol Annu Rev 18:155-250

Engstrom NA (1982) Brooding behaviour and reproductive biology of a subtidal Puget Sound sea cucumber Cucumaria lubrica (Clark 1901) (Echinodermata: Holothuroidea). In: Lawrence JM (ed) International Echinoderm Conference, Tampa Bay. AA Balkema, Rotterdam, p 447-450

Fankboner PV (1978) Suspension-feeding mechanisms of the armoured sea cucumber Psolus chitinoides Clark. J Exp Mar Biol Ecol 31:11-25
Fankboner PV, Cameron JL (1985) Seasonal atrophy of the visceral organs in a sea cucumber. Can $\mathrm{J}$ Zool 63: $2888-2892$

Ferguson JC (1969) Feeding, digestion, and nutrition in Echinodermata. In: Florkin M, Scheer BT (eds) Chemical Zoology, Vol. IIr. Echinodermata, Nematoda and Acanthocephala. Academic Press, New York, p 71-100

Fish JD (1967) Biology of Cucumaria elongata. J Mar Biol Assoc UK 47:129-143

Francour P (1997) Predation on holothurians: a literature review. Invertebr Biol 116:52-60

Fréchette $M$, Bourget $E$ (1985) Energy flow between the pelagic and benthic zones: factors controlling particulate organic matter available to an intertidal mussel bed. Can J Fish Aquat Sci 42:1158-1165

Gladfelter WB (1978) General ecology of the cassiduloid urchin Cassidulus caribbearum. Mar Biol 47:149-160

Grizzle RE, Morin PJ (1989) Effect of tidal currents, seston, and bottom sediments on growth of Mercenaria mercenaria: results of a field experiment. Mar Biol 102:85-93

Hamel JF, Mercier A (1996) Early development, settlement, growth, and spatial distribution of the sea cucumber Cucumaria frondosa (Echinodermata: Holothuroidea).Can $J$ Fish Aquat Sci 53:253-271

Hamel JF, Mercier A. (1998) Diet and feeding behaviour of the sea cucumber Cucumaria frondosa in the St. Lawrence estuary, eastern Canada. Can J Zool 76:1194-1198

Hammond LS (1982) Patterns of feeding and activity in deposit-feeding holothurians and echinoids (Echinodermata) from a shallow back-reef lagoon, Discovery Bay, Jamaica. Bull Mar Sci 32:549-571

Harvell D, LaBarbera M (1985) Flexibility: a mechanism for control of local velocity in hydroid colonies. Biol Bull 168: $312-320$

Holland ND, Leonard AB, Strickler JR (1987) Upstream and downstream capture during suspension feeding by Oligometra serripinna (Echinodermata: Crinoidea) under surge conditions. Biol Bull 173:552-556

Hunter T (1989) Suspension feeding in oscillatory flow: the effects of colony morphology and flow regime on plankton capture by the hydroid Obelia longissima. Biol Bull 176 . $41-49$

Hunter-Rowe KA, Jeal F. West AB (1977) Observations on the feeding behaviour of Thyone fusus (Müller, OF). Sci Proc R Dublin Soc (Ser A.) 5:459-468

Hyman LH (1955) The invertebrates, Vol 4 . Echinodermata. McGraw-Hill, New York

Jespersen A, Lutzen J (1971) On the ecology of the aspidochirote sea cucumber Stichopus californicus (Gunnerus). Norw J Zool 19:117-132

Jordan AJ (1972) On the ecology and behavior of Cucumaria frondosa (Echinodermata: Holothuroidea) at Lamoine Beach, Maine. PhD thesis, University of Maine, Orono, MA

Jørgensen CB (1966) Biology of suspension feeding. Pergamon Press, Oxford

Jørgensen CB (1990) Bivalve filter-feeding: hydrodynamics, bioenergetics, physiology and ecology. Olsen and Olsen, Fredensborg

Könnecker G, Keegan BF (1973) In situ behavioural studies on echinoderm aggregations. Helgol Wiss Meeresunters 24: 157-162

LaBarbera M (1978) Particle capture by a Pacific brittle star: experimental test of the aerosol suspension feeding model. Science 201:1147-1149

LaBarbera $M$ (1984) Feeding currents and particle capture mechanisms in suspension feeding animals. Am Zool 24: $71-84$ 
Lacalli T (1981) Annual spawning cycles and planktonic larvae of benthic invertebrates from Passamaquoddy Bay, New Brunswick. Can J Zool 59:433-440

Lasker HR (1981) A comparison of the particulate feeding abilities of three species of gorgonian soft coral. Mar Ecol Prog Ser 5:61-67

Lawrence JM, Hughes-Games L (1972) The diurnal rhythm of feeding and passage of food through the gut of Diadema setosum (Echinodermata: Echinoidea). Israel J Zool 21 $13-16$

Leonard AB (1989) Functional response in Antedon mediterranea (Lamarck) (Echinodermata: Crinoidea): the interaction of prey concentration and current velocity on a passive suspension-feeder. J Exp Mar Biol Ecol 127: $81-103$

Leonard AB, Strickler JR, Holland ND (1988) Effects of current speed on filtration during suspension feeding in Oligometra serripinna (Echinodermata: Crinoidea). Mar Biol 97:111-125

Leversee GJ (1976) Flow and feeding in fan-shaped colonies of a gorgonian coral, Leptogorgia. Biol Bull 151:344-356

Loo LO, Jonsson PR, Sköld M, KarIsson Ö (1996) Passive suspension feeding in Amphiura filiformis (Echinodermata: Ophiuroidea): feeding behaviour in flume flow and potential feeding rate of field populations. Mar Ecol Prog Ser 139:143-155

MacGinite GE, MacGinite N (1949) Natural history of marine mammals. McGraw-Hill, New York

Mackenzie CL Jr (1970) Feeding rates of the starfish Asterias forbesi (Desor), at controlled water temperatures and during different seasons of the year. US Fish Wildl Serv Fish Bull 68:67-72

Magnus DBE (1963) Der Federstern Heterometra savignyj im Roten Meer. Natur Mus Frankf 93:355-368

Martin JL, Wildish DJ, LeGresley MM, Ringuette M (1995) Phytoplankton monitoring in the Southwestern Bay of Fundy during 1990--1992. Can Manuscr Rep Fish Aquat Sci $2277: 1-154$

Massin C (1982) Food and feeding mechanisms: Holothuroidea. In: Jangoux M, Lawrence JM (eds) Echinoderm nutrition. AA Balkema, Rotterdam, p 43-53

Mauzey KP (1966) Feeding behavior and reproductive cycles in Pisaster ochraceus. Biol Bull 131:127-144

Mauzey KP, Birkeland C, Dayton PK (1968) Feeding behavior of asteroids and escape responses of their prey in the Puget Sound region. Ecology 49:603-619

Meyer DL (1979) Length and spacing of the tube feet in crinoids (Echinodermata) and their role in suspensionfeeding. Mar Biol 51:361-369

Meyer DL, Lane NG (1976) The feeding behavior of some Paleozoic crinoids and recent basket stars. J Paleontol 50 : $472-480$

Mori S, Matutani K (1952) Studies on the daily rhythmic activity of the starfish. Astropecten polyacanthus Müller et Troschel, and the accompanied physiological rhythms. Publ Seto Mar Biol Lab 2:213-225

Mosher C (1965) Notes on natural evisceration of the sea cucumber Actinopyga agassizi Selenka. Bull Mar Sci Gulf Caribb 15:255-258

Muschenheim DK (1987) The dynamics of near-bed seston flux and suspension-feeding benthos. J Mar Res 45: $473-496$

Nelson BV, Vance RR (1979) Diel foraging patterns of the sea urchin Centrostephanus coronatus as a predator avoidance strategy. Mar Biol 51:251-258

Ölscher EM, Fedra K (1977) On the ecology of a suspension feeding benthic community: filter efficiency and behav- iour. In: Keegan BF, Ceidigh PO, Boaden PJS (eds) Biology of benthic organisms. Pergamon Press, Oxford, p 483-492

Parsons TR, Maita Y, Lalli CM (1984) A manual of chemical and biological methods for seawater analysis. Pergamon Press, New York

Patterson MR (1984) Patterns of whole colony prey capture in the octocoral, Alcyonium siderium. Biol Bull 167:613-629

Patterson MR (1991a) Passive suspension feeding by an octocoral in plankton patches: empirical test of a mathematical model. Biol Bull 180:81-92

Patterson MR (1991b) The effects of flow on polyp-level prey capture in an octocoral, Alcyonium siderium. Biol Bull 180: 93-102

Pawson DL (1966) Ecology of holothurians. In: Boolootian RA (ed) Physiology of Echinodermata. John Wiley and Sons, New York, p 63-71

Pawson DL, Caycedo IE (1980) Holothuria (Thymiosycia) thomasi n. sp., a large Caribbean coral reef inhabiting sea cucumber (Echinodermata: Holothuroidea). Bull Mar Sci $30: 454-459$

Peterson CH, GA Skilleter (1994) Control of foraging behavior of individuals within an ecosystem context: the clam Macoma balthica, flow environment, and siphon-cropping fishes. Oceologia 100:256-267

Reese ES (1966) The complex behaviour of echinoderms. In: Boolootian RA (ed) Physiology of Echinodermata. John Wiley and Sons, New York, p 157-218

SAS (1988) Statistical Analysis System, Release 6.03. SAS Institute Inc, Cary, NC

Schaller F (1973) Über die Tentaklebewegungen der dendrochiroten Holothurien Cucumaria lefevri und $C$. saxicola. Zool Anz 191:162-170

Shimeta J, Jumars PA (1991) Physical mechanisms and rates of particle capture by suspension feeders. Oceanogr Mar Biol Annu Rev 29:191-257

Shimeta J, Koehl MAR (1997) Mechanisms of particle selection by tentaculate suspension feeders during encounter, retention, and handling. J Exp Mar Biol Ecol 209:47-73

Singh R, MacDonald BA, Lawton P. Thomas MLH (1998) The feeding response of the dendrochirote sea cucumber Cucumaria frondosa (Echinodermata: Holothuroidea) to changing food concentrations in the laboratory. Can J Zool $76: 1842-1849$

Skilleter GA, Peterson $\mathrm{CH}$ (1994) Control of individuals within an ecosystem context: the clam Macoma balthica and interactions between competition and siphon cropping. Oecologia 100:268-278

Sloan NA (1980) Aspects of the feeding biology of asteroids. Oceanogr Mar Biol Annu Rev 18:57-124

Smith TB (1983) Tentacular ultrastructure and feeding behav. iour of Neopentadactyla mixa (Holothuroidea: Dendrochirota). J Mar Biol Assoc UK 63:301-311

Smith TB, Keegan BF (1985) Seasonal torpor in Neopentadactyla mixta (Östergren) Echinodermata, Holothuroidea. In: Keegan BF, O'Connor BDS (eds) Echinodermata: Proc 5th Int Echinoderm Conference, Galway, Ireland, 24-29 September 1984. AA Balkema, Rotterdam, p 459-464

Sponaugle S, LaBarbera M (1991) Drag-induced deformation: a functional feeding strategy in two species of gorgonians. J Exp Mar Biol Ecol 148:121-145

Steir TJB (1933) Diurnal changes in activities and geotropism in Thyone briareus. Biol Bull 15:259-288

Strickland JDH, Parsons TR (1972) A practical handbook of seawater analysis, 2nd edn. Bull Fish Res Bd Can 167

Tanaka Y (1958) Feeding and digestive processes of Stichopus japonicus. Bull Fac Fish. Hokkaido Univ 9:14-28 
Trites RW, Garrett CJR (1983) Physical oceanography of the Quoddy Region. In: Thomas MLH (ed) Marine and coastal systems of the Quoddy Region, New Brunswick. Can Spec Publ Fish Aquat Sci $64: 9-34$

Wamer GF (1977) On the shapes of passive suspension feeders. In: Keegan BF, Ceidigh PO, Boaden PJS (eds) Biology of benthic organisms. Pergamon Press, Oxford, p 567-576

Wiedmeyer WL (1993) Feeding behaviour of two tropical holothurians Holothuria (Metriatyla) scabra (Jäger 1833) and $H$. (Halodeima) atra (Jäger 1833), from Okinawa, Japan. In: Richmond RH (ed) Proc 7 th Int Coral Reef Symp, Guam, 22-27 June 1992, Vol 2. University of Guam Press, Mangilao, p 853-860

Yamanouti $\mathrm{T}$ (1942) The feeding habits of the Namako (Sti-

Editorial responsibility: Charles Peterson (Contributing Editor), Morehead City, North Carolina, USA. chopus japonicus Selenka). Zool Mag (Tokyo) 54:344-346 (Translated from Japanese by Can Transl Fish Aquat Sci 5080, 1984)

Yentsch CS, Menzel DW (1963) A method for the determination of phytoplankton chlorophyll and phaeophytin by fluorescence. Deep-Sea Res 10:221-231

Yingst JY (1982) Factors influencing rates of sediment ingestion by Parastichopus californicus (Clark), an epibenthic deposit-feeding holothurian. Estuar Coast Shelf Sci 14: $119-134$

Young CM, Emson RH (1995) Rapid arm movements in stalked crinoids. Biol Bull 188:89-97

Zar JH (1984) Biostatistical analysis, 2nd edn. Prentice-Hall Inc, Englewood Cliffs, NJ

Submitted: April 30, 1998; Accepted: April 20, 1999

Proofs received from author(s): October 8, 1999 